\title{
HUBUNGAN KEMAMPUAN MENGGUNAKAN KATA PENGHUBUNG DENGAN KEMAMPUAN MENYUSUN KALIMAT MENJADI PARAGRAF DEDUKTIF
}

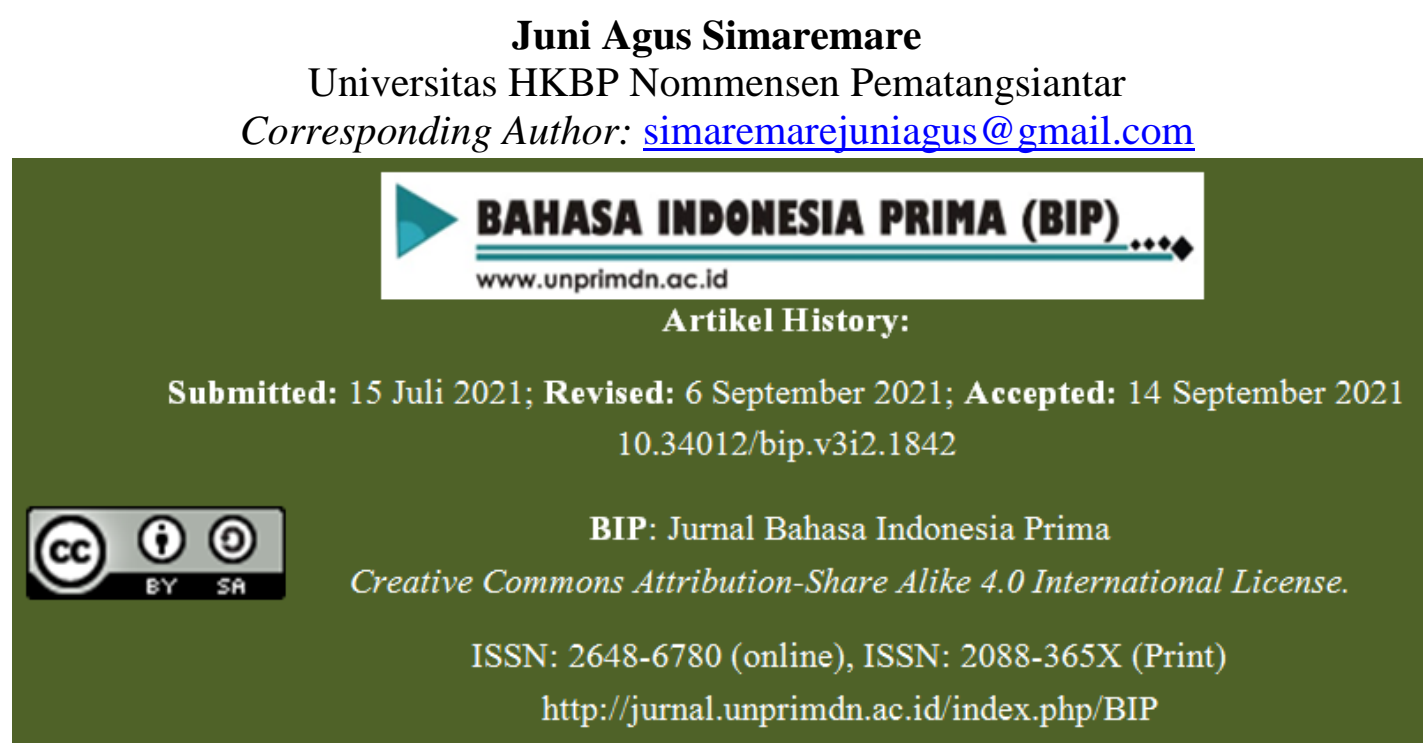

Abstrak-Penelitian ini bertujuan untuk mengetahui bagaimana hubungan antara kemampuan menggunakan kata penghubung dengan kemampuan menyusun kalimat menjadi paragraf deduktif oleh siswa kelas XI SMA Negeri 1 Muara. Populasi Penelitian ini adalah seluruh siswa kelas XI SMA Negeri 1 Muara yang berjumlah 200 orang. Sampel penelitian diambil $15 \%$ dari jumlah populasi yaitu 30 orang dengan teknik random sampling. Metode yang digunakan dalam penelitian ini adalah metode deskriptif korelasional. Alat pengumpulan data yang digunakan adalah tes pilihan berganda. Pengujian Hipotesis dilakukan dengan menggunakan rumus korelasi Product Moment $\left(\mathrm{r}_{\mathrm{xy}}\right)$. Setelah $r_{x y}$ diketahui, selanjutnya dikonsultasikan dengan $r_{\text {tabel }}$ pada taraf signifikan 5\% dan $1 \%$ dengan $\mathrm{N}=30$ yaitu $(0,361$ dan 0,463). Karena $r_{x y}$ yang diperoleh dari $r_{\text {tabel }}$ yaitu 0,531>0,361 dan 0,531>0,463, maka hipotesis alternative (Ha) diterima. Hal ini berarti terdapat hubungan positif yang signifikan antara kemampuan menggunakan kata penghubung dengan kemampuan kemampuan menyusun kalimat menjadi paragraf deduktif oleh siswa kelas XI SMA Negeri 1 Muara.

Kata kunci: kata penghubung, kalimat, paragraf deduktif

Abstract-This study aims to determine how the relationship between the ability to use conjunctions with the ability to compose sentences into deductive paragraphs by class XI students of SMA Negeri 1 Muara. The population of this study were all students of class XI SMA Negeri 1 Muara, amounting to 200 people. The research sample was taken $15 \%$ of the total population, namely 30 people with random sampling technique. The method used in this research is descriptive correlational method. The data collection tool used is a multiple choice test. Hypothesis testing is done by using the Product Moment $\left(r_{x y}\right)$ correlation formula. After $r_{x y}$ is known, then it is consulted with $r_{\text {tebel }}$ at a significant level of $5 \%$ and $1 \%$ with $N=30$, namely (0.361 and 0.463). Because $r_{x y}$ obtained from $r_{\text {tabel }}$ is 0,531>0,361 and 
$0,531>0,463$, then the alternative hypothesis $(\mathrm{Ha})$ is accepted. This means that there is a significant positive relationship between the ability to use conjunctions and the ability to compose sentences into deductive paragraphs by class XI students of SMA Negeri 1 Muara.

Keywords: conjunction, sentence, deductive paragraph

\section{A. Pendahuluan}

Bahasa merupakan alat komunikasi yang digunakanseseorang untuk berkomunikasi dengan orang lain. Seperti yang dikatakan Keraf (1990:2) bahwa bahasa adalah alat komunikasi antar anggota masyarakat, berupa lambang bunyi ujaran, yang dihasilkan oleh alat ucap manusia. Komunikasi tersebut dapat dilakukan secara lisan maupun tulisan. Komunikasi dengan menggunakan tulisan berarti harus diawali dengan aktivitas menulis. Menulis adalah menyampaikan informasi kepada orang lain (pembaca) dapat dipahami dengan benar, diperlukan keterampilan menulis yang baik.

Meskipun pembelajaran menulis sering dipelajari siswa di sekolah dari tingkat pendidikan dasar, tampaknya masih sering menemui kesulitan dalam menulis, hal ini ditandai dengan sering ditemukannya kesalahan-kesalahan siswa dalam menulis paragraf, khususnya paragraf deduktif. Kesalahan-kesalahan tersebut tentunya menyebabkan informasi yang disampaikan oleh penulis tidak semakna dengan informasi yang dimaksud pembaca.

Kesalahan-kesalahan yang dilakukan siswa dalam menulis paragraf sangat kompleks, paragraf yang tersusun tidak koheren dan penggunaan kata penghubung dalam kalimat maupun antar kalimat yang kurang tepat. Sering penulis melihat siswa salah menggunakan kata penghubung, misalnya kata penghubung yang seharusnya ditulis "dengan" namun ditulis "dan", begitu juga dengan kata "kepada" ditulis "terhadap". Kesalahan-kesalahan tersebut mengindikasikan bahwa siswa belum memahami fungsi kata penghubung dalam kalimat. Kesalahan ini juga dihadapi oleh peneliti ketika melakukan penilaian penulisan artikel oleh siswa kelas XI SMA Negeri 1 Muara. Dari hasil penilaian tersebut masih banyak siswa yang belum mampumenggunakan kata penghubung baik di dalam intra kalimat,antar kalimat, maupun antar paragraf. Siswa selalu mengalami kesulitan menggunakan kata penghubung sesuai dengan fungsinya. Hal di atas memberikan gambaran bahwa siswa kelas XI SMA Negeri 1 Muara tidak mampu menyusun paragraf deduktif dengan benar ditinjau dari aspek penggunaan kalimat.

Rendahnya kemampuan menulis siswa di atas perlu dicari solusinya salah satu diantaranya adalah dengan melakukan penelitian apakah rendahnya kemampuan siswa menulis kalimat dalam paragraf deduktif ada hubungannya dengan pengetahuan mereka tentang penggunaan kata penghubung. Secara umum tujuan dari penelitian ini adalah untuk mengetahui hubunganantara kemampuan menggunakan kata penghubung dengan kemampuan menyusun kalimat menjadi paragraf deduktif oleh siswa kelas XI SMA Negeri 1 Muara Tahun Pembelajaran 2010/2011

Alwi dkk (2003:296) "mengatakan, kata penghubung/kata sambung adalah kata tugas yang menghubungkan dua satuan bahasa yang sederajat; kata dengan kata, frasa dengan frasa, atau klausa dengan klausa". Selanjutnya Keraf (1984:79) "mengatakan kata penghubung/kata sambung adalah kata 
BIP: Jurnal Bahasa Indonesia Prima Vol. 3, No. 2, 2021, September 2021, PP.

yang menghubungkan kata, bagian-bagian kalimat, atau menghubungkan kalimatkalimat". Menurut Badudu (1999:135) "Kata penghubung/kata sambung adalah kata yang dipakai untuk merangkaikan kalimat dengan kalimat atau merangkaikan bagian-bagian kalimat". Berdasarkan pendapat-pendapat tersebut dapat disimpulkan bahwa kata penghubung adalah kata yang berfungsi menghubungkan antar kata dengan kata, klausa dengan klausa, kalimat dengan kalimat, dan antar paragraf. Kata penghubung disebut juga sebagai kata sambung atau konjungsi.

Alwi dkk (2003:297) mengatakan, dilihat dari perilaku sintaksisnya dalam kalimat, kata penghubung dibagi atas tiga bagian yaitu kata penghubung koordinatif, korelatif, dan subordinatif.

Kata penghubung koordinatif adalah kata yang menghubungkan dua unsur atau lebih yang sama pentingnya, atau memiliki status yang sama. Yang termasuk di dalamnya adalah dan, serta, atau, tetapi, melainkan, padahal, dan sedangkan.

Kata penghubung korelatif adalah kata yang menghubungkan dua kata,frase, atau klausa yang memiliki status sintaksis yang sama. Kata ini terbagi atas dua bagian yang dipisahkan oleh salah satu kata, frase, atau klausa yang dihubungkan.

1) Baik... maupun...

2) Tidak hanya...tetapi juga

3) Bukan hanya...melainkan juga...

4) Demikian ...sehingga...

5) entah...entah...

6) Sedemikian rupa... sehingga

7) jangankan...,...pun...

Kata penghubung subordinatif adalah kata yang menghubungkan dua klausa atau lebih dan klausa itu tidak memiliki status sintaksis yang sama. kelompok-kelompok kata penghubung subordinatif adalah:

1) Kata penghubung subordinatif waktu (sejak, semenjak, sedari.sewaktu, ketika, tatkala, sementara, begitu, seraya, selagi, selama, serta, sambil, demisetelah, sesudah, sebelum, sehabis, seusai, selesai, hingga, sampai dan lain-lain).

2) Kata penghubung subordinatif syarat (jika, kalau, jikalau, asal(kan), bila,manakala.

3) Kata penghubung subordinatif pengandaian (andaikan seandainya, umpamanya, sekiranya).

4) Kata penghubung subordinatif tujuan (agar, supaya, biar)

5) Kata penghubung subordinatif konsesif (biarpun, meskipun, walaupun, sekalipun, sungguhpun, kendatipun)

6) Kata penghubungsubordinatif perbandingan (seakan-akan, seolaholah, sebagaimana, seperti, sebagai, laksana, ibarat, daripada, alih-alih)

7) Kata penghubung subordinatif sebab (sebab, karena, oleh karena itu, oleh sebab)

8) Kata penghubung subordinatif hasil (sehingga, sampai (-sampai), maka (nya)

9) Kata penghubung subordinatif alat (dengan, tanpa)

10) Kata enghubung subordinatif cara (dengan, tanpa)

11) Kata penghubung subordinatif komplementasi (bahwa)

12) Kata penghubung subordinatif atributif (yang)

13) Kata penghubung subordinatif perbandingan (sama...dengan, lebih...dari (pada)

Ramlan (2005:27) mengatakan,

"Kalimat adalah satuan gramatik yang 
dibatasi oleh adanya jeda panjang yang disertai nada akhir turun atau naik." Menurut Arifin (2008:54) "Kalimat adalah satuan bahasa yang secara relative berdiri sendiri, mempunyai intonasi final (kalimat lisan) dan secara actual ataupun potensial terdiri atas klausa." Selanjutnya Keraf (1984 :141) mengatakan bahwa kalimat adalah satu bagian ujaran yang di dahului dan diikuti oleh kesenyapan sedangkan intonasinya menunjukkan bahwa bagian ujaran itu sudah lengkap.

Dalam KBBI (2005:828) mengatakan, "Paragraf adalah bagian bab dalam suatu karangan (biasanya mengandung satu ide pokok dan penulisannya dimulai dengan garis baru; alinea)." Sedangkan menurut Kosasih (2003:22), mengatakan paragraf merupakan bagian dari kerangka (tertulis) atau bagian dari tuturan (lisan). Sebuah paragraf ditandai oleh suatu kesatuan gagasan yang lebih tinggi atau lebih luas daripada kalimat.Kalimat-kalimat itu saling bertalian untuk mengungkapkan sebuah gagasan tertentu."

Arifin (2008:83) mengatakan, "Paragraf deduktif adalah gagasan utama terletak pada bagian awal paragraf." .Kosasih (2003:23) mengatakan, “ Paragraf deduktif adalah paragraf yang gagasan utamanya terletak di awal paragraph." Berdasarkan kedua pendapat tersebut dapat disimpulkan bahwa paragraf deduktif adalah paragraf yang gagasan utama/ide pokoknya berada di awal paragraf. Gagasan utaman atau pokok persoalan itu dinyatakan dalam kalimat pertama.

Keraf (1979:67) mengatakan, "Alinea yang baik dan efektif harus memenuhi ketiga syarat yaitu Kesatuan, Koherensi, Perkembangan alinea.

1. Kesatuan: yang dimaksud dengan kesatuan dalam alinea adalah bahwa semua kalimat yang membina alinea itu secara bersama-sama menyatakan suatu hal, suatu tema tema tertentu.

2. Koherensi: yang dimaksud dengan koherensi adalah kekompakan hubungan antara sebuah kalimat dengan kalimat yang lain yang membentuk alinea itu.

3. Perkembangan alinea: perkembangan alinea adalah penyusunan atau perincian daripada gagasan-gagasan yang membina alinea itu.

Selanjutnya Kosasih (2003:25) mengatakan, "Paragraf yang baik adalah paragraf yang memiliki kepaduan antara unsure-unsurnya, baik itu antara gagasan utama dengan gagasan penjelasnya ataupun antar kalimat- kalimatnya. Kepaduan pada paragraf terbagi ke dalam dua macam, yakni kepaduan makna dan kepaduan bentuk.

\section{B. Metode Penelitian}

Penelitian ini menggunakan metode deskriptif. Penelitian ini dilaksanakan di SMA Negeri 1 Muara Tahun Pembelajaran 2011/2012. populasi dalam penelitian ini adalah seluruh siswa kelas XI SMA Negeri 1 Muara Tahun Pembelajaran 2010/2012 yang berjumlah 200 orang.

Arikunto (2006: 134) mengatakan, Untuk sekedar ancer-ancer, maka apabila subjeknya kurang dari 100 lebih baik diambil semua sehingga penelitiannya merupakan penelitian populasi.Tetapi, jika jumlah subjeknya besar, dapat diambil antara $10-15 \%$ atau $20-25 \%$ atau lebih. Berdasarkan hal tersebut, maka jumlah sampel yang diambil dalam penelitian ini sebanyak $15 \%$ dari populasi yang ada yaitu $15 \% \times 200$ orang $=30$ orang.

Sukardi (2003 : 75) Mengatakan, "Secara fungsional kegunaan intrumen penelitian adalah untuk memperoleh data yang diperlukan ketika peneliti sudah 
menginjak pada langkah pengumpulan informasi di lapangan." Selanjutnya, Arikunto (2006:149) mengatakan, "Instrumen adalah alat pada waktu penelitian menggunakan suatu metode." Berdasarkan pendapat tersebut metode penelitian adalah suatu alat yang digunakan untuk mengumpulkan data dari subjek yang diteliti.

Alat pengumpulan data yang digunakan dalam penelitian ini adalah tes objektif (dalam bentuk pilihan berganda).Jumlah soal yang digunakan untuk menjaring masing-masing variable adalah 20 soal. Untuk setiap jawaban yang benar diberi bobot skor (1) sedangkan jawaban yang salah diberi bobot (0).

Uji coba instrument dilakukan untuk mengetahui kesahihan (validitas), tingkat keterpercayaan (reliabilitas) alat ukur. Uji coba instrument tes dilakukan dalam dua tahap yaitu uji validitas dan uji reliabilitas.

Teknik analisis data dilakukan dengan menggunakan langkah-langkah sebagai berikut:

1. Menentukan skor kemampuan menggunakan kata penghubung dalam kalimat dengan menghitung jawaban yang benar

2. Mengubah skor menjadi nilai akhir dengan cara jumlah jawaban yang benar dibagi jumlah soal dikali 100 .

3. Menentukan skor kemampuan menyusun paragraf deduktif.

4. Mencari hubungan kemampuan menggunakan kata penghubung dengan kemampuan menyusun paragraf deduktif

5. Melakukan uji persyaratan:

a. Uji normalitas

b. Uji linearitas

Untuk mendeskripsikan data kemampuan menggunakan kata penghubung dengan dengan kemampuan menyusun paragraf deduktif digunakan statistik deskripsi yaitu dengan menghitung rata-rata skor(M), Standar Deviasi (SD) dengan rumus sebagai berikut :

$\mathrm{M}=\frac{\sum \mathbf{X}}{\mathbf{N}}$

$\mathrm{M}$ = rata-rata skor

$\mathrm{SD}=$ Sta dar Deviasi

$\mathrm{N}=$ Jumlah sampel

$\sum \mathrm{X}=$ Jumlah produk butir $\mathrm{X}$

Penelitian ini bersifat korelasional (hubungan) yang bersifat parametrik, untuk itu data yang dikorelasikan harus memiliki dua syarat yaitu data berdistribusi normal dan antara variable $X$ dengan variable $\mathrm{Y}$ menunjukkan gejala yang linear. Untuk itu dilakukan uji normalitas dan linearitas

a. Uji Normalitas

Uji normalitas dilakukan dengan menggunakan Rumus Chi kuadrat :

$\mathbf{X}^{\mathbf{2}}=\sum \frac{\left(\mathbf{f}_{\mathbf{0}}-\mathbf{f}_{\mathbf{h}}\right)^{\mathbf{2}}}{\mathbf{f}_{\mathbf{h}}}$

Keterangan:

$\mathrm{X}^{2}=$ Chi kuadrat

$f_{o} \quad=$ Frekuensi Observasi

$f_{h}=$ Frekuensi harapan

Ketentuan yang digunakan adalah jika $\boldsymbol{x}_{\text {hitung }}{ }^{2} \boldsymbol{x}_{\text {tabel }}{ }_{\text {tabe }}$ pada taraf signifikan 5\% dengan $\mathrm{db}=\mathrm{k}-1$, maka data penelitian berdistribusi normal.

b. Uji Linearitas

Uji linearitas dilakukan dengan menggunakan regresi $\mathrm{Y}=\mathrm{a}+\mathrm{bx}$.

Selanjutnya untuk menguji lineritas digunakan rumus :

$\mathbf{F}_{\mathbf{o}}=\frac{\mathbf{S}^{2}(\mathrm{TC})}{\mathbf{S}^{2}(\mathbf{S})}$

Ketentuan yang digunakan adalah:

Jika $\boldsymbol{f}_{\text {hitung }}<\boldsymbol{f}_{\text {tabel }}$ pada taraf signifikan 5\% maka disimpulkan bahwa data penelitian adalah linier. 
Untuk mengetahui kebenaran hipotesis yang dirumuskan, maka digunakan rumus korelasi Product Moment $\left(\mathrm{r}_{\mathrm{xy}}\right)$ Rumus korelasi product moment dilakukan dengan menggunakan rumus angka kasar sebagai berikut :

$\mathbf{r}_{\mathbf{x y}}=\frac{\mathbf{N} \sum \mathbf{X Y}-\left(\sum \mathbf{X}\right)\left(\sum \mathbf{Y}\right)}{\sqrt{\left\{\left(\mathbf{N} \sum \mathbf{X}^{2}-\left(\sum \mathbf{X}\right)^{2}\right\}\left\{\mathbf{N} \sum \mathbf{Y}^{2}-\left(\sum \mathbf{Y}\right)^{2}\right\}\right.}}$

Keterangan :

$\mathrm{N}=$ Jumlah subjek

$\sum \mathrm{X}=$ Jumlah skor variabel $\mathrm{X}$

$\sum \mathrm{Y}=$ Jumlah skor variabel $\mathrm{Y}$

$\sum X^{2}=$ Jumlah kuadrat skor variabel $\mathrm{X}$ $\sum \mathrm{Y}^{2}=$ Jumlah kuadrat skor variabel $\mathrm{Y}$

$\sum X Y=$ Jumlah hasil perkalian $\mathrm{X}$ terhadap $\mathrm{Y}$

Selanjutnya nilai $\boldsymbol{r}_{\text {hitung }}$ akan dikonsultasikan dengan harga $\boldsymbol{r}_{\text {tabel }}$ pada tarafsignifikansi $5 \%$ atau $\alpha 0,05$ dengan ketentuan :

a. Terima hipotesis kerja $\left(\mathrm{H}_{\mathrm{a}}\right)$ jika $\boldsymbol{r}_{\text {hitung }} \geq \boldsymbol{r}_{\text {tabel }}$

b. Terima hipotesis nihil $\left(\mathrm{H}_{0}\right)$ jika

$$
\boldsymbol{r}_{\text {hitung }}<\boldsymbol{r}_{\text {tabel }}
$$

\section{Hasil dan Pembahasan}

Dari hasil analisis korelasi anatara kemampuanmenggunakankata

penghubung (X) dengan kemampuan menyusun kalimat menjadi paragraf deduktif (Y) diperoleh harga koefisien 0,531 dan setelah dikonsultasikan dengan $\mathrm{r}$ tabel pada taraf signifikan 95\% $(0,361)$ dan pada taraf signifikan 99\% $(0,463)$. Dengan demikian rh > rt $(0,588>0,361)$ dan $(0,588>0,463)$, sehingga hipotesis menyatakan terdapat hubungan yang signifikan antara kemampuan menggunakan kata penghubung dengan kemampuan menyusun kalimat menjadi paragraf deduktif teruji kebenaranya dan hipotesis kerja diterima.

Berdasarkan pendapat diatas dengan harga koefisien korelasi seebesar 0,588 dapat disimpulkan bahwa variabel dalam penelitian ini memiliki korelasi yang cukup

Berdasarkan hasil penelitian, penulis memperoleh gambaran bahwa hubungan kemampuan menggunakan kata penghubung dengan kemampuan menyusun kalimat menjadi paragraf deduktif siswa kelas XI SMA Negeri 1 muara Tahun Pembelajaran 2010/2011 dapat dikategorikan tinggi.

Hal ini dapat dibuktikan dari rata-rata kemampuan menggunakan kata penghubung yaitu 13 orang (44\%) berada pada kategori sedang dan 17 orang (56\%) berada pada kategori tinggi sedangkan skor kemampuan menyusun kalimat menjadi paragraf deduktif adalah tinggi dengan 14 orang $(46 \%)$ berada pada kategori sedang dan 16 orang (54\%) berada pada kategori tinggi. Berdasarkan hasil uji korelasi ditemukan bahwa hubungan kemampuan menggunkan kata penghubung memiliki korelasi yang cukup (sebesar 0,588). Jadi, ada hubungan yang signifikan antara kemampuan menggunakan kata penghubung dengan kemampuan menyusun kalimat menjadi paragraf deduktif siswa kelas XI SMA Negeri 1 Muara Tahun Pembelajaran 2010/2011.

\section{Simpulan}

Berdasarkan hasil penelitian dan pembahasan pada BAB IV di atas, maka dapat di tarik kesimpulan sebagai berikut:

1. Kemampuan menggunakan kata penghubung siswa kelas XI SMA Negeri 1 Muara Tahun Pembelajaran 2010/2011 berada pada kategori tinggi ( 13 orang memiliki nilai sedang, dan 17 orang memiliki nilai tinggi.

2. Kemampuan menyusun kalimat menjadi paragraf deduktif kelas XI SMA Negeri 1 Muara Tahun 
BIP: Jurnal Bahasa Indonesia Prima Vol. 3, No. 2, 2021, September 2021, PP.

Pembelajaran 2010/2011 berada pada kategori tinggi (14 orang memiliki nilai sedang, 16 orang memiliki nilai tinggi.

3. Ada hubungan yang signifikan antara kemampuan menggunakan kata penghubung dengan kemapuan menyusun kalimat menjadi paragraf deduktif siswa kelas XI SMA Negeri 1 Muara Tahun Pembelajaran 2010/2011. Hal ini diketahui dari uji hipotesis dengan $\quad r_{\text {hitung }}>r_{\text {tabal }}$ baik taraf signifikan $5 \%$ maupun $1 \%$ yaitu $0,588>0,361$ dan 0,588 >0,463. Dapat disimpulkan bahwa hubungan kemampuan menggunakan kata penghubung dengan kemampuan menyusun kalimat menjadi paragraf deduktif memiliki nilai korelasi yang cukup.

\section{Daftar Pustaka}

Ali, Muhammad. Kamus Lengkap Bahasa Indonesia Modern. Jakarta: Pustaka Amani

Alwi, dkk. 2003. Tata Bahasa Baku Bahasa Indonesia. Jakarta: Balai Pustaka

Arifin, Zaenaldan Junaiyah. 2008. Sintaksis. Jakarta : Grasindo

Arikunto, Suharsimi. 2006. Prosedur Penelitian Suatu Pendekatan Praktik. Jakarta:Rineka Cipta

Badudu, J.S. 1999. Pelik-Pelik Bahasa Indonesia. Bandung: Pustaka Prima

Chaer, Abdul. 2007. Linguistik Umum. Jakarta: Rineka Cipta

Debdiknas. 2005. Kamus Besar Bahasa Indonesia. Jakarta: Balai Pustaka
Keraf, Gorys. 1990. Tata Bahasa Rujukan Bahasa Indonesia. Jakarta: Nusa Indah

Kosasih, H. E. 2003. Ketatabahasaan dan Kesusastraan. Bandung: Yrama Widya

Nurgiyantoro, Burhan. 1988. Penilaian Dalam Pengajaran Bahasa dan Sastra. Yogyakarta: BPFE

Ramlan, M. 2005. Morfologi Suatu Tinjauan Deskriptif. Yogyakarta: Karyono

Sudjana. 2005. Metoda Statistika. Bandung: Tarsito

Sugiono. 2009. Metode Penelitian Pendidikan. Bandung: Alfabeta

Sukardi. 2003. Metodologi Penelitian Pendidikan. Yogyakarta: Bumi Aksara

Tarigan, H.G. 1984. Pengajaran Sintaksis. Bandung: Angkasa 